\title{
PENDIDIKAN MULTIKULTURAL DALAM PERSPEKTIF ILMU PENDIDIKAN ISLAM (IPI)
}

\author{
Fitri Handayani, Uus Ruswandi, Mohamad Erihadiana, Muhammad Hasan Basari \\ UIN Sunan Gunung Djati Bandung \\ Universitas Islam Nusantara Bandung \\ fitrihandayani078@gmail.com | uusruswandi@uinsgd.ac.id | \\ erihadiana@uinsgd.ac.id | basarihasan.hb@gmail.com
}

\begin{abstract}
Various cultures, ethnicities, languages, skin colors, ethnicities, customs, religions and beliefs as well as various conflicts in Indonesia, but united with the motto "Bhinneka Tunggal Ika", different but one thing. This can be realized strategically through multicultural education in formal, informal and non-formal education. Multicultural education is an idea, an educational renewal movement and an educational process that aims to change the structure of educational institutions so that all students who are members of racial, ethnic and cultural groups can have the opportunity to achieve achievement. Multicultral education needs to be optimized in arranging the dynamics of diversity to become a potential for human progress and civilization towards piety. Multicultural education is "Education for All", which is education for all people and prioritizes equal rights. Multicultural education can be implemented in education in Indonesia and is in line with Islamic education. Through multicultural education, Islamic education will expand its spread and become a blessing for all nature in achieving happiness in the world and the hereafter.
\end{abstract}

Key Word: diversity; multicultural; Islamic education

\begin{abstract}
Abstrak
Beraneka ragam budaya, suku, bahasa, warna kulit, etnis, adat, agama dan kepercayaan serta berbagai konflik di Indonesia, namun dipersatukan dengan semboyan "Bhinneka Tunggal Ika", berbeda-beda namun satu jua. Hal ini bisa diwujudkan secara strategis melalui pendidikan multikultural pada pendidikan formal, informal dan nonformal. Pendidikan multikultural merupakan ide, gerakan pembaharuan pendidikan dan proses pendidikan yang bertujuan untuk mengubah struktur lembaga pendidikan supaya semua peserta didik menjadi anggota kelompok ras, etnis, dan kultur dapat memiliki kesempatan untuk mencapai prestasi. Pendidikan multikultural perlu dioptimalkan dalam menata dinamika keragaman untuk menjadi potensi kemajuan dan peradaban manusia menuju ketakwaan. Pendidikan multikultural merupakan "Education for $A l l$ " yakni pendidikan untuk semua orang dan mengutamakan persamaan hak. Pendidikan multikultural dapat diimplementasikan pada pendidikan di Indonesia dan selaras dengan ilmu pendidikan islam. Melalui pendidikan multikultural, ilmu pendidikan Islam akan semakin meluas penyebarannya dan menjadi rahmat bagi seluruh alam dalam mencapai kebahagiaan dunia dan akhirat.
\end{abstract}

Kata Kunci: keberagaman; multikultural; pendidikan Islam 


\section{A. Pendahuluan}

Indonesia merupakan negara yang beraneka ragam budaya, suku, bahasa, warna kulit, etnis, adat, agama dan kepercayaan serta berbagai konflik yang berbeda, namun tetap satu semboyan negara "Bhinneka Tunggal Ika", berbeda-beda namun satu jua. Hal ini berkaitan dengan paradigma multikulturalisme, dimana multikulturalisme bisa diwujudkan secara strategis melalui pendidikan multikultural dalam pendidikan. Baik pendidikan formal, informal maupun pendidikan non-formal. Pada pembelajaran secara langsung atau pembelajaran tidak langsung.

Keberagaman seperti ini tentunya harus diciptakan sebuah sistem pendidikan yang multikultural sehingga dapat mencakup semua unsur masyarakat. Pendidikan dan Multikultural merupakan solusi atas realitas budaya yang beragam sebagai sebuah proses pengembangan seluruh potensi yang menghargai pluralitas dan heterogenitas sebagai konsekuensi berbagai keberagaman.

Multikultural dalam rangka pemberdayaan masyarakat yang majemuk dan heterogen agar saling memahami dan menghormati serta membentuk karakter yang terbuka terhadap perbedaan. Salah satu upayanya adalah melalui pendidikan yang multikultural. Demikian pula dengan ilmu pendidikan islam, bertujuan mewujudkan pendidikan sebagai pelestari sebagai agen of culture yang berdasarkan al-Qur'an, hadits dan ijma.

Pendidikan multikultural merupakan pendidikan khas Barat, diantaranya Kanada, Amerika, Jerman dan Inggris. Amerika serikat didorong oleh tuntutan warga Amerika latin dan Afrika, bahwa warga pribumi dan kelompok marginal yang menuntut persamaan hak dan kesempatan dalam mengenyam pendidikan. 
Dalam perspektif ilmu Pendidikan Islam di Indonesia, pendidikan multikultral ini perlu dioptimalkan sebaik mungkin untuk menata dinamika keragaman agar dapat menjadi potensi kemajuan dan peradaban manusia menuju ketakwaan. Sebagaimana dalam al-Qur'an Surat al-Hujurat Ayat 13 yakni:

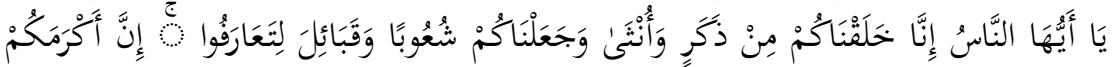

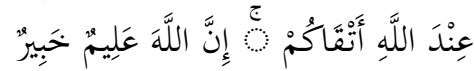

Artinya: "Hai manusia, sesungguhnya Kami menciptakan kamu dari seorang laki-laki dan seorang perempuan dan menjadikan kamu berbangsa-bangsa dan bersuku-suku supaya kamu saling kenal-mengenal. Sesungguhnya orang yang paling mulia di antara kamu di sisi Allah ialah orang yang paling takwa di antara kamu. Sesungguhnya Allah Maha Mengetahui lagi Maha Mengenal."

Apabila mengkaji ayat di atas, hal ini menunjukan bahwa multikultural sudah merupakan ketentuan yang Allah siapkan atau merupakan sunatullah yang pasti adanya bagi setiap negarabangsa di dunia ini. Diartikan sebagai Rahmat Allah yang telah menciptakan manusia yang beranekaragam. Keberadaan tersebut secara positip saling melengkapi satu sama lain.

Pendidikan multikultural merupakan proses pendidikan yang menyeluruh dan mendasar bagi seluruh peserta didik. Menurut Muhaemin el-Ma'hady dalam Sopiah menyatakan bahwa pendidikan multikultural dapat didefinisikan sebagai pendidikan tentang keragaman kebudayaan dalam merespon perubahan demografis dan kultural lingkungan masyarakat tertentu atau bahkan duinia secara keseluruhan. ${ }^{1}$

Hal ini senada dengan pernyataan Pendidikan multikultural merupakan "Education for All" yakni pendidikan yang diberikan untuk semua orang dan mengutamakan persamaan hak, sehingga pendidikan adalah hak semua orang. Melalui pendidikan multikultural, membangun keberagaman yang tentunya dapat mencakup semua unsur masyarakat namun tetap memperhatikan kearifan lokal, sehingga sistem pendidikan di Indonesia dapat diterapkan konsep pendidikan multikultural.

\footnotetext{
1 Muhaemin el-Ma'hady "Multikulturalisme dan Pendidikan Multikultural", dalam Forum Tarbiyah Vol. 7, No. 2, Desember 2009.
} 
Melalui pendidikan multikultural, pendidikan menurut Undang Undang Sisdiknas tahun 2003 sebagaimana disebutkan dalam pasal 4 (1), Bab III tentang Prinsip Penyelenggaraan Pendidikan, disebutkan bahwa "Pendidikan diselenggarakan secara demokratis dan berkeadilan serta tidak diskriminatif dengan menjunjung tinggi hak asasi manusia, nilai keagamaan, nilai kultural dan kemajemukan bangsa.

Tujuan utama penulisan ini adalah bahwa pendidikan multikultural ini sesuai dengan ilmu pendidikan islam yang memmpunyai konsep bahwa semua manusia sama, seluruh peserta didik mempunyai hak yang sama dalam mengenyam pendidikan sehingga dapat memperoleh prestasi akademik dalam pendidikan.

Sebagaimana tujuan pendidikan multikultural ini adalah untuk menciptakan kehidupan yang harmonis dalam masyarakat yang majemuk. Banks dalam Ilham Mirsal menyatakan: ${ }^{2}$

Multicultural education is an idea, an educational reform movement, and a process whose major goal is to change the structure of educational institutions so that male and female students, exceptional students, and students who are members of diverse racial, ethnic, and cultural groups will have an equal chance to achieve academically in school.

Pendidikan multikultural adalah ide, gerakan pembaharuan pendidikan dan proses pendidikan yang tujuan utamanya adalah untuk mengubah struktur lembaga pendidikan supaya siswa, baik pria maupun wanita, siswa berkebutuhan khusus, dan siswa yang merupakan anggota dari kelompok ras, etnis, dan kultur yang bermacam-macam itu akan memiliki kesempatan yang sama untuk mencapai prestasi akademis di sekolah.

${ }^{2}$ James A. Bank, (ed), Multicultural Education: Issues and Perspectives (London: Allyn and Bacon Press, 1989). 


\section{B. Metode}

Penelitian ini menggunakan metode analisis deskriptif dengan mendeskripsikan tentang pendidikan multikultural dalam perspektif ilmu pendidikan islam (IPI). Penelitian ini menggunakan sumber data sekunder, diantaranya adalah web, jurnal, dan buku-buku yang relevan dengan pendidikan multikultural dalam perspektif ilmu pendidikan Islam. Pendekatan yang digunakan dalam penelitian ini adalah pendekatan kualitatif. Analisis data kualitatif ini terdiri dari alur kategorisasi, reduksi data, penyajian data dan simpulan.

\section{Pembahasan}

Pendidikan multikultural berasal dari dua kata, yakni pendidikan dan multikultural. Pendidikan merupakan proses pengembangan sikap dan tata laku seseorang atau sekelompok orang dalam usaha mendewasakan manusia melalui pengajaran, pelatihan, proses, perbuatan dan cara-cara yang mendidik.

Sebagaimana Ki Hadjar Dewantara merumuskan pendidikan adalah daya upaya untuk memajukan bertumbuhnya budi pekerti (kekuatan batin, karakter), pikiran (intelek), dan tubuh anak. Dapat dikatakan pula pendidikan ini adalah Transfer of knowledge atau memindah ilmu pengetahuan dari seorang pendidik terhadap peserta didik atau upaya memanusiakan manusia. Sementara multikultural secara etimologis yakni terdiri dari multi yang berarti banyak, beragam atau aneka, dan kultural yang berasal dari kata culture bermakna budaya, tradisi.

Multikultural dapat diartikan sebagai keragaman budaya. Istilah lainnya yang biasanya digunakan untuk keberagaman, baik agama, ras, bahasa dan budaya yang berbeda, yaitu pluralitas (plurality), keragaman (diversity) dan multikultural (multicultural). Multikulturalisme menurut Parsudi Suparlan merupakan sebuah ideologi yang mengakui dan mengagungkan perbedaan dalam kesederajatan, baik secara individual maupun secara kebudayaan. ${ }^{3}$

${ }^{3}$ Parsudi Suparlan, "Menuju Masyarakat Indonesia yang Multikultural", dalam makalah 2002. 
Pendidikan multikultural menurut Banks dalam Ilham Mirsal menyatakan bahwa: ${ }^{4}$

Multicultural education is an idea, an educational reform movement, and a process whose major goal is to change the structure of educational institutions so that male and female students, exceptional students, and students who are members of diverse racial, ethnic, and cultural groups will have an equal chance to achieve academically in school.

Pendidikan multikultural adalah ide, gerakan pembaharuan pendidikan dan proses pendidikan yang tujuan utamanya adalah untuk mengubah struktur lembaga pendidikan supaya siswa, baik pria maupun wanita, siswa berkebutuhan khusus, dan siswa yang merupakan anggota dari kelompok ras, etnis, dan kultur yang bermacam-macam itu akan memiliki kesempatan yang sama untuk mencapai prestasi akademis di sekolah.

Sementara menurut Tilaar pendidikan multikultural ${ }^{5}$ berawal dari berkembangnya gagasan dan kesadaran tentang "interkulturalisme" seusai perang dunia II. Kemunculan gagasan dan kesadaran "interkulturalisme" ini selain terkait dengan perkembangan politik internasional menyangkut HAM, kemerdekaan dari kolonialisme, dan diskriminasi rasial dan lainlain, juga karena meningkatnya pluralitas di negara-negara Barat sendiri sebagai akibat dari peningkatan migrasi dari negaranegara baru merdeka ke Amerika dan Eropa.

Pendidikan multikultural merupakan "Education for All" yakni pendidikan yang diberikan untuk semua orang dan mengutamakan persamaan hak, sehingga pendidikan adalah hak semua orang. Melalui pendidikan multikultural, membenagun keberagaman yang tentunya dapat mencakup semua unsur masyarakat namun tetap memperhatikan kearifan lokal, sehingga sistem pendidikan di Indonesia dapat diterapkan konsep pendidikan multikultural.

${ }^{4}$ James A. Bank, (ed), Multicultural Education: Issues and Perspectives (London: Allyn and Bacon Press, 1989).

5 H.A.R. Tilaar, Multikulturalisme: Tantangan-Tantangan Global Masa Depan dalam Transformasi Pendidikan Nasional (Jakarta: Grasindo, 2002). 
Hal ini senada dengan pendidikan menurut Undang Undang Sisdiknas tahun 2003 sebagaimana disebutkan dalam pasal 4 (1) tentang Prinsip Penyelenggaraan Pendidikan, disebutkan bahwa "Pendidikan diselenggarakan secara demokratis dan berkeadilan serta tidak diskriminatif dengan menjunjung tinggi hak asasi manusia, nilai keagamaan, nilai kultural dan kemajemukan bangsa.

Tujuan pendidikan multikultural berorintasi ke masyarakatan yang menganggap pendidikan sebagai sarana utama dalam menciptakan rakyat yang baik, baik untuk sistem pemerintahan demokratis.

Tujuan pendidikan multikultural lain diantaranya yakni dapat memfungsikan peranan sekolah dalam memandang keberadaan siswa yang beraneka ragam, membantu siswa dalam membangun perlakuan yang positif terhadap perbedaan kultural, ras, etnik, kelompok keagamaan, memberikan ketahanan siswa dengan cara mengajar mereka dalam mengambil keputusan dan keterampilan sosial, membantu peserta didik dalam membangun ketergantungan lintas budaya dan memberi gambaran positif kepada mereka mengenai perbedaan kelompok.

Sementara tujuan dan prinsip pendidikan multikultural menurut Gorsky adalah bahwa setiap siswa mempunyai kesempatan untuk mengembangkan prestasi mereka, siswa belajar bagaimana belajar dan berpikir secara kritis, mendorong siswa untuk mengambil peran aktif dalam pendidikan, menghadirkan pengalaman-pengalaman mereka dalam konteks belajar, mengakomodasikan semua gaya belajar siswa, mengapresiasi kontribusi dari kelompok-kelompok yang berbeda, mengembangkan sikap positif terhadap kelompok-kelompok yang mempunyai latar belakang yang berbeda, menjadi warga negara yang baik di sekolah maupun di masyarakat, belajar bagaimana menilai pengetahuan dari perspektif yang berbeda, mengembangkan identitas etnis, nasional dan global, selanjutnya mengembangkan ketrampilan-ketrampilan mengambil keputusan dan analisis secara kritis sehingga siswa dapat membuat pilihan yang lebih baik dalam kehidupan sehari-hari. 
Perbedaan-perbedaan pada diri peserta didik harus diakui dalam pendidikan multikultural, sehingga peserta didik diberi kesempatan dan pilihan untuk mendukung dan memperhatikan satu atau beberapa budaya, misalnya sistem nilai, gaya hidup, atau bahasa. Pendidikan harus berpedoman pada prinsip keseimbangan, keterbukaan, dinamis, fleksibel, situasional dan kondsisonal, egaliter, demokratis, manusiawi, rasional professional dan kualitatif. $^{6}$

Hal ini sesuai dengan prinsip ilmu pendidikan Islam yang mengakomodir kebutuhan manusia. yang tidak lain bertujuan mewujudkan pendidikan sebagai pelestari sebagai agen of culture yang berdasarkan al-Qur'an, hadits dan ijma.

Ilmu Pendidikan Islam diarahkan pada upaya mewujudkan tujuan dari kehadiran Islam (maqashid al-syari'ah) itu sendiri melalui pendekatan nilai-nilai islami yaitu memelihara, membina, membimbing, dan memenuhi kebutuhan manusia dalam bidang agama, akal, jiwa, harta dan keturunan. Dalam arti kata, bukan sebatas memberti ilmu pengetahuan kepada pikiran peserta didik saja dengan dan materi pelajaran, melainkan dapat membersihkan jiwanya yang harus diisi dengan akhlak dan nilai-nilai yang baik dan dikondisikan supaya biasa menjalani hidup dengan baik atau menciptakan kehidupan yang harmonis dalam masyarakat yang serba majemuk.

Terkait pendidikan multikultural dalam Perspektif Ilmu Pendidikan Islam, bahwa ruang lingkup Ilmu Pendidikan Islam sangat luas, karena di dalamnya banyak pihak-pihak yang ikut terlibat baik secara langsung atau tidak langsung.

Islam sebagai agama yang mewajibkan umatnya untuk menuntut ilmu dalam mengenyam pendidikan, bertujuan untuk meninggikan derajat bagi yang berilu pengetahuan,dalam mensejahterakan dan membahagiakan hidup di dunia dan di akhirat.

\footnotetext{
${ }^{6}$ Abudin Nata Filsafat Pendidikan Islam, cet-1 (Jakarta: Logos Wacana Ilmu, 1997).
} 
Dalam ilmu pendidikan Islam, hal ini memiliki kaitan atau hubungan dengan konteks waktu dan tempat yang melingkupinya dalam berbagai perbedaan. Sebagaiman firman Allah dalam alQur'an surat al-Hujurat ayat 13:

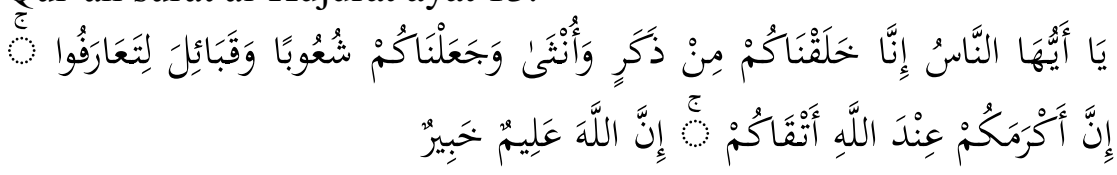

Artinya: "Hai manusia, sesungguhnya Kami menciptakan kamu dari seorang laki-laki dan seorang perempuan dan menjadikan kamu berbangsa-bangsa dan bersuku-suku supaya kamu saling kenal-mengenal. Sesungguhnya orang yang paling mulia diantara kamu disisi Allah ialah orang yang paling takwa diantara kamu. Sesungguhnya Allah Maha Mengetahui lagi Maha Mengenal."

Berdasarkan ayat tersebut, jelaslah, ini menandakan pluralitas manusia. Ilmu pendidikan islam yang mengedepankan al-Quran sangat menyadari bahwa manusia berbeda beda, namun, perbedaan ini bukan dijadikan sebagai potensi untuk saling mengenal dan bermanfaat satu sama yang lainnya.

Tafsir al-Misbah dalam Tejo Waskito dan Miftahur Rahman $^{7}$ dijelaskan bahwa, sesungguhnya Kami (Allah Swt) menciptakan manusia dari seorang laki-laki dan seorang perempuan adalah pengantar untuk menegaskan bahwa semua derajat kemanusiaannya sama disisi Allah Swt. Tidak ada perbedaan antara satu golongan dengan golongan yang lain. Tidak ada perbedaan pada nilai kemanusiaan antara laki- laki dan perempuan, karena semua manusia diciptakan dari seorang lakilaki dan perempuan.

Allah juga menjadikan manusia dengan bersuku-suku, berbangsa-bangsa dan berkelompok-kelompok. Semua mendapat perlakuan yang sama oleh Allah Swt. Tujuannya hanya satu, yaitu "li ta"arafu" (saling mengenal satu sama lain secara baik). Pengantar tersebut mengantar pada kesimpulan bahwa "sesungguhnya yang paling mulia diantara kamu disisi Allah Swt. adalah yang paling bertaqwa".

7 Tejo Waskito dan Miftahur Rohman, "Pendidikan Multikultural Perspektif al-Qur'an”, dalam, Jurnal Tarbawi: Jurnal Ilmu Pendidikan, Vol 14, No. 02, Desember 2018, 29-43. 
Hal yang membedakan manusia satu dengan yang lain bukan terletak pada sukunya, rasis ataupun bahasanya, tetapi lebih kepada tingkat ketaqwaannya kepada Allah Swt. Karena itu, berusahalah untuk meningkatkan ketaqwaan agar menjadi yang termulia disisi Allah Swt.

Dalam perspektif ilmu pendidikan islam, pendidikan multikultural dalam masyarakat yang heterogen, setiap masyarakat memiliki fungsi- fungsi tertentu dalam hubungan sosial, baik itu pada skala kecil seperti maupun skala besar dalam masyarakat luas dengan keragaman etnis, budaya, dan agama yang memiliki tempat tersendiri dalam membangun kebersamaan untuk eksistensi bersama.

Setiap perbedaan memiliki peranan yang penting dalam mewujudkan peran dan mewujudkan kebersamaan, dengan demikian, sudah seharusnya setiap individu maupun kelompok memiliki rasa tanggung jawab terhadap kelestarian, ketenteraman, dan kesejahteraan dalam mewujudkan eksistensi kebersamaan tanpa memandang perbedaan.

Dalam ayat al-Qur'an lainnya sebagai pedoman dari Ilmu pendidikan islam yang membahas tentang Pendidikan multikultural diantaranya tertuang dalam surat ar-Rum-ayat-22

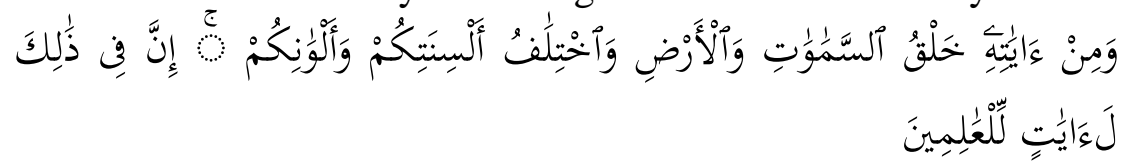

Artinya: "Dan diantara tanda-tanda kekuasaan-Nya ialah menciptakan langit dan bumi dan berlain-lainan bahasamu dan warna kulitmu. Sesungguhnya pada yang demikan itu benarbenar terdapat tanda-tanda bagi orang-orang yang mengetahui."

M. Quraish Shihab dalam Tejo Waskito dan Miftahur Rohman menjelaskan, ${ }^{8}$ di bumipun terdapat sekian banyak tandatanda kekuasaan Allah Swt. Disini yang disinggung adalah yang terdapat dalam diri manusia sekaligus dengan peredaran matahari dan bumi. Lebih lanjut Quraish Shihab mengatakan bahwa yang disebutkan ialah perbedaan lidah, ini karena terjadi perbedaan tempat tinggal di bumi.

8 Tejo Waskito dan Miftahur Rohman, "Pendidikan Multikultural Perspektif al-Qur'an", dalam, Jurnal Tarbawi: Jurnal Ilmu Pendidikan, Vol 14, No. 02, Desember 2018. 
Demikian juga warna kulit, antara lain dipengaruhi oleh sinar matahari. Ayat tersebut menekankan tentang perbedaan, karena perbedaan itu lebih menonjolkan kuasa-Nya. Betapa tidak, manusia berbeda-beda dalam segala aspek, padahal manusia lahir dari sumber yang sama. Kata alsinatikum adalah jamak dari lisan yang berarti lidah. Ia juga digunakan dalam arti lidah dan suara. Penelitian terakhir menunjukkan bahwa tidak seorangpun yang memiliki suara yang sepenuhnya sama dengan orang lain. Persis seperti sidik jari.

Berdasarkan hal tersebut, pendidikan multikultural dengan membawa konsep pluralitas dan heterogenitas bahasa, budaya, ras, dan agama sudah menjadi bagian urgen yang tak terpisahkan dari ilmu pendidikan islam yang sangat menghormati dan menghargai terhadap perbedaan.

Hakekatnya perbedaan itu adalah sebuah rahmat, bagi manusia yang mau berfikir serta berkewajiban toleransi terhadap pluralitas dan heterogenitas karena hal ini sesuai dengan landasan atau dasar dari ilmu pendidikan Islam, yakni:

Pertama, al-Qur'an yang merupakan landasan utama dalam ilmu pendidikan Islam. Al-Qur'an merupakan kebenaran yang disampaikan oleh Allah Swt dan dengan demikian Allah adalah pendidik utama manusia yang memberikan ilmu dan ajaran kebenaran agar manusia dapat menjalani hidupnya dengan baik dan sesuai syariat agama Islam. Hal ini disebutkan dalam firman Allah surat al-Baqarah ayat 2.

Kedua, adalah Hadits (segala ucapan, perbuatan dan takrir Rasulullah Saw), yang merupakan suri tauladan atau uswatun hasanah bagi seluruh umat manusia. Sebagai figure yang patut dicontoh oleh semua umat manusia karena membawa risalah kebenaran yang akan menuntun ke jalan kebahagiaan di dunia dan akherat sebagaimana tertuang dalam QS al-Ahzab: 21.

Dalam ilmu pendidikan islam kedudukan hadits memiliki dua fungsi yakni menjelaskan hal yang bersifat umum yang ada dalam al-Qur'an dan memberi pengertian tentang cara hidup Rasulullah Saw serta bagaimana perlakuannya terhadap orang lain. 
Ketiga, yang menjadi landasan dalam ilmu pendidikan islam adalah Ijtihad sahabat, ulama, dan para cendekiawan muslim. Supaya dpat mengambil kemaslahatan umat. Ijtihad diperlukan mengingat karena hidup selalu ada perubahan sesuai perkembangan zaman, semua kejadian di masa modern ini tidak dijelaskan secara rinci dalam al-Qur'an dan hadits sehingga memerlukan petunjuk dalam ijtihad.

Keempat, landasan atau dasar dalam ilmu pendidikan islam warisan pemikiran Islam untuk mengatasi masalah di kemudian hari. Warisan pemikiran islam dari para ulama juga merupakan wujud refleksi ilmu pendidikan islam itu sendiri dan dinamika islam yang senantiasa mengikuti perkembangan zaman.

Ditinjau dari segi tujuan pendidikan multikultural yang secara garis besar sesuai dengan tujuan Ilmu pendidikan Islam, agar hidup manusia dapat berjalan dengan seimbang dan sejahtera. Berikut ini adalah tujuan pendidikan islam secara menyeluruh, yakni yang pertama memberi petunjuk bagi manusia agar umat manusia dapat menjalankan tugasnya sebagai khalifah Tuhan dimuka bumi dengan sebaik-baiknya serta dapat mengelola alam sesuai dengan apa yang dikehendaki Allah Swt sebagaimana tertuang dalam QS. al-Baqarah: 30. Kedua, menyadarkan peran manusia sebagai khalifah. Sebagai suatu ibadah kepada Allah Swt. Ketiga, membimbing umat manusia agar memiliki akhlak dan perilaku yang mulia dalam bergaul dengan sesamanya atau makhluk lainnya serta alam sekitar. Keempat, membina potensi manusia agar dapat memaksimalkan potensi jiwa, raga dan akal agar dapat menuntut ilmu dan memiliki keterampilan yang dapat mendukung tugasnya sebagai khalifah di muka bumi.

Berdasarkan paparan di atas, untuk melaksanakan pendidikan dan pengajaran dapat diimplementasikan dengan memasukan nilai-nilai multikultural pada setiap materi bahasan maupun pendekatan pembelajaran dalam kajian ilmu pendidikan islam. Pendidikan multikultural dapat diterapkan dan sesuai dengan ilmu pendidikan islam. Melalui pendidikan multikultural, ilmu pendidikan Islam akan semakin meluas dan bermanfaat sehingga menjadi rahmat bagi seluruh alam membawa kebahagiaan di dunia dan akherat. 


\section{Penutup}

Ilmu Pendidikan Islam diarahkan pada upaya mewujudkan tujuan dari kehadiran Islam (maqashid al-syari'ah) itu sendiri melalui pendekatan nilai-nilai islami yaitu memelihara, membina, membimbing, dan memenuhi kebutuhan manusia dalam bidang agama, akal, jiwa, harta dan keturunan. Dalam arti kata, bukan sebatas memberti ilmu pengetahuan kepada pikiran peserta didik saja dengan dan materi pelajaran, melainkan dapat membersihkan jiwanya yang harus diisi dengan akhlak dan nilai-nilai yang baik dan dikondisikan supaya biasa menjalani hidup dengan baik atau menciptakan kehidupan yang harmonis dalam masyarakat yang serba majemuk.

Hakekatnya perbedaan itu adalah sebuah rahmat, bagi manusia yang mau berfikir serta berkewajiban toleransi terhadap pluralitas dan heterogenitas karena hal ini sesuai dengan landasan atau dasar dari ilmu pendidikan islam.

Pendidikan multikultural dapat diimplementasikan pada pendidikan di Indonesia, baik jalur pendidikan formal, informal maupun non formal dan sesuai dengan ilmu pendidikan islam. Melalui pendidikan multikultural, ilmu pendidikan Islam akan semakin meluas dan menjadikan ilmu pendidikan islam yang menjadi rahmat bagi seluruh alam membawa kebahagiaan di dunia dan akhirat. 


\section{Daftar Pustaka}

A. Bank, James (ed), Multicultural Education: Issues and Perspectives, London: Allyn and Bacon Press, 1989.

El-Ma'hady, Muhaemin "Multikulturalisme dan Pendidikan Multikultural", dalam Forum Tarbiyah Vol. 7, No. 2, Desember 2009.

Nata, Abudin Filsafat Pendidikan Islam, cet-1, Jakarta: Logos Wacana Ilmu, 1997.

Suparlan, Parsudi, "Menuju Masyarakat Indonesia yang Multikultural", dalam makalah 2002.

Tilaar, H.A.R. Multikulturalisme: Tantangan-Tantangan Global Masa Depan dalam Transformasi Pendidikan Nasional, Jakarta: Grasindo, 2002.

Undang Undang Sisdiknas tahun 2003 pasal 4 (1), Bab III tentang Prinsip Penyelenggaraan Pendidikan.

Waskito, Tejo dan Miftahur Rohman, "Pendidikan Multikultural Perspektif al-Qur'an", dalam, Jurnal Tarbawi: Jurnal Ilmu Pendidikan, Vol 14, No. 02, Desember 2018.

http://journal.iaincurup.ac.id.

http://journal.iainkudus.ac.id.

https://assunnah.ac.id.

https://tafsirweb.com. 